В. М. Михальчук, В. В. Горачук, В. В. Краснов, О. К. Толстанов, О. Л. Нестерець Національна медична академія післядипломної освіти імені П. Л. Шупика, м. Київ

\title{
АДАПТИВНЕ НАВЧАННЯ КЕРІВНИКІВ ЗАКЛАДІВ ОХОРОНИ ЗДОРОВ’Я ЯК ПЕРЕДУМОВА ФОРМУВАННЯ КОМПЕТЕНТНІСНОГО ПІДХОДУ ДО ЇХ ПРОФЕСІЙНОЇ ПІДГОТОВКИ
}

\author{
V. M. Mykhalchuk, V. V. Horachuk, V. V. Krasnov, O. K. Tolstanov, O. L. Nesterets \\ Shupyk National Medical Academy of Postgraduate Education, Kyiv \\ ADAPTIVE TRAINING OF HEALTHCARE INSTITUTIONS MANAGERS \\ AS A PREREQUISITE FOR THE FORMATION OF COMPETENCY-BASED \\ APPROACH TO PROFESSIONAL TRAINING
}

\begin{abstract}
Мета роботи - розгляд адаптивного навчання керівників закладів охорони здоров’я та визначення його ролі щодо формування компетентнісного підходу до професійної підготовки керівних кадрів у сфері охорони здоров’я.

Основна частина. Проведено розгляд основних наукових термінів, що характеризують поняття адаптивного навчання. Головним чинником результативності освіти, компетентності людини, динамічного становлення і розвитку особистості згідно $з$ їі потребами та запитами суспільства є здатність самостійно пристосовуватися до змін в освіті у ході засвоєння знань і вмінь. Адже основними процесами в адаптивному навчанні є самоаналіз, самооцінювання, саморозвиток, самореалізація, самоадаптація.

У процесі підготовки керівника закладу охорони здоров'я на основі реалізації адаптивного навчання професійно доцільною є фахово-педагогічна взаємодія між фахівцем та науково-педагогічним працівником, що дозволяє забезпечити керівника закладу охорони здоров’я багатогранними професійними знаннями, комплексно-кваліфікаційними вміннями, здатностями їх застосовувати в різних робочих ситуаціях.

Висновки. Застосування адаптивного навчання керівників закладів охорони здоров’я, спрямоване на вирішення значущих навчальних задач із застосуванням професійно-орієнтованого індивідуального підходу до навчання, сприятиме розвитку особистісних якостей, необхідних для продуктивної роботи стосовно запровадження реформ, вирішення назрілих галузевих проблем, прогнозування очікуваних результатів, а також взаємодії з медичним колективом та пацієнтами.
\end{abstract}

Ключові слова: адаптивне навчання; професійна підготовка; післядипломна освіта; керівники закладів охорони здоров’я.

The aim of the study - to consider adaptive learning of healthcare institutions managers and defining its role in the formation of competency-based approach to training public health personnel.

The main body. Basic scientific document, describing the concept of adaptive learning are reviewed. The main factor in the impact of education, human expertise, dynamic attitude and personality development in accordance with its needs and demands of society is our ability to adapt to changes in education during the learning and skills. After all, the basic processes in the adaptive learning are self-examination, self-assessment, self-improvement, self-realization, self-adaptability.

In healthcare institution manager's training through implementation of appropriate adaptive learning professional is professionalpedagogical interaction between experts and scientific teaching staff, allowing for healthcare institution manager multifaceted professional knowledge, skills and qualification complex, the ability to apply them in various work situations.

Conclusion. The use of adaptive learning managers of public health aimed at solving important educational problems using professionally-oriented individual approach to learning, contribute to the development of personal qualities necessary for productive work regarding the implementation of reforms, addressing pressing industry problems, predicting outcomes, and interact with medical staff and patients.

Key words: adaptive learning; professional training; lifelong learning; healthcare institution manager.

Вступ. Наразі в Україні одним із ключових питань державної політики є питання реформування вітчизняної сфери охорони здоров’я. Одним із

() В. М. Михальчук, В. В. Горачук, В. В. Краснов та ін. головних завдань реформування медичної галузі $€$ вироблення відповідної національної кадрової політики. Відбуваються важливі зміни в системі вищої медичної освіти, які пов’язані з потребою 
підготовки нового покоління висококваліфікованих управлінських кадрів.

Пріоритетом освіти є підготовка фахівців з необхідними професійними знаннями, уміннями та навичками, створення умов для їх постійного розвитку й удосконалення компетентності в межах обраної спеціальності, особистісного розвитку і становлення. Це обумовлено вимогами Концепції розвитку вищої медичної освіти в Україні [1], Національною стратегією розвитку освіти в Україні на період до 2021 року [2], Законом України “Про вищу освіту” [3] тощо.

Враховуючи те, що на сучасному етапі розвитку в нашій державі відбуваються процеси налагодження медичного обслуговування висококваліфікованими медичними кадрами, актуальною стає потреба удосконалення підготовки діючих та майбутніх керівників закладів охорони здоров'я.

У цьому контексті проблема особистісного становлення керівника закладу охорони здоров'я $є$ найважливішою, адже становлення головного лікаря, який, крім високих професійних якостей, мав би здатність до сприйняття нововведень, вміння стратегічно мислити та прогнозувати очікувані результати, добре орієнтуватись у фінансових питаннях, ухвалювати комплексні рішення, встановлювати та підтримувати взаємовідносини з людьми, дало б можливість отримати компетентного управлінця з гармонічним поєднанням лідерських та організаторських якостей.

У зв’язку з цим, більш високими є вимоги до змісту і якості навчального процесу, його адекватності реальним завданням, що розв’язуються керівними медичними фахівцями на різних етапах професійної діяльності. Сучасний керівник закладу охорони здоров'я має не лише знати, а й ефективно діяти як у запланованих, так і непередбачуваних ситуаціях, самостійно розробляти інноваційні технології управління, усвідомлювати суспільну значущість своєї праці та державну відповідальність за їі результати. Успіх підготовки такого фахівця залежить від становлення і розвитку його особистісно-професійних якостей.

Вивчення принципів адаптивного навчання розпочалося із педагогічних праць А. В. Дістервега, Я. А. Коменського й І. Г. Песталоцці. Зокрема, А. В. Дістервег писав: "Починай викладання з того, на чому зупинився учень... Без знання того, на чому зупинився учень, неможливо добре навчити його” [4]. Також питання адаптації в освіті, в тому числі професійній, розглядалися в значній кількості наукових праць філософів, педагогів і психологів В. П. Андрущенко, А. Бандури, В. Бондар, Т. А. Борової, Л. С. Виготського, Г. В. Єльникова, Г. С. Костюка, Н. Ф. Кузьміної, С. Д. Максименко, Л. М. Мітіної, Т. Л. Опалюк, Г. А. Полякової, В. А. Семиченко, І. Шапошнікової та ін. [5-8]. Однак проблемам адаптивного навчання в медичній освіті присвячено не так багато наукових досліджень [9-11].

Мета роботи - розгляд адаптивного навчання керівників закладів охорони здоров'я та визначення його ролі щодо формування компетентнісного підходу до професійної підготовки керівних кадрів у сфері охорони здоров’я.

Основна частина. Нові підходи до освітнього процесу в системі післядипломної підготовки керівних кадрів сфери охорони здоров'я в Україні впровадили поняття адаптивного навчання. Пов'язані із цим видом навчання наукові терміни потребують певного розгляду. Адаптація - це процес пристосування людини до змінених умов, нових вимог, наявних традицій із наступним звиканням до них. Адаптація зазвичай приводить до моральних, психологічних, біофізіологічних змін в організмі особистості, суб'єктності вже сформованої індивідуальності, оскільки потребує напруженої й цілеспрямованої роботи над собою: ставленням, поведінкою, характером, самооцінкою тощо [5].

Адаптивне навчання - явище з широким спектром впливу особистості на оточуюче їі освітнє, соціальне, морально-етичне середовище або, навпаки - впливу зовнішніх і внутрішніх чинників на особистість [5].

Навчання професії - це процес, що характеризується формуванням індивідуального стилю професійного мислення і діяльності та підготовкою до входження в систему виробничих і соціальних відносин [5].

Усі перераховані процеси мають відбуватися синхронно в тісній взаємодії науково-педагогічних працівників і слухачів, тому що адаптивний процес може бути ефективним тільки за умови охоплення обох сторін. Висока професійна компетентність науково-педагогічного працівника дає можливість формувати навчальну діяльність слухачів на діалогічній основі, організовувати навчання як спільний узгоджений процес для реалізації навчально-професійних завдань. Головним механізмом професійно-орієнтованого навчання є взаємодія досвідів того, хто вчить, і того, хто навчає, реалізація якої 
можлива лише тоді, коли науково-педагогічний працівник сприймає слухача як особистість. При подібній взаємодії науково-педагогічний працівник насамперед має враховувати особливості слухачів, з якими організовується навчальна діяльність, рівень їх актуального розвитку, інтелектуальних можливостей, пізнавального інтересу, рівень сформованості навчальної діяльності (вміння вчитися), здатність до оцінно-рефлексивної діяльності та ін. Врахування індивідуально-типологічних особливостей слухачів є також формою адаптації науковопедагогічного працівника до суб’єкта навчальної взаємодії, а отже, і до реальних умов навчальної діяльності.

Головним чинником результативності освіти, компетентності людини, динамічного становлення і розвитку особистості згідно з її потребами та запитами суспільства є здатність самостійно пристосовуватися до змін в освіті у ході засвоєння знань і вмінь. Адже основними процесами в адаптивному навчанні є самоаналіз, самооцінювання, саморозвиток, самореалізація, самоадаптація.

Найбільш коректно адаптивне навчання використовується в системі післядипломної освіти [11]. Через істотну різницю в рівні базової підготовки й індивідуальних здібностей слухачів однаковий для всіх план навчального процесу, прийнятий за основу в традиційних системах навчання, $є$ оптимальним у кращому разі лише для 15-30 \% слухачів: для одних він занадто напружений, для інших, навпаки, недостатньо інтенсивний. У результаті неефективно використовуються інтелектуальні й матеріальні ресурси як індивіда, так і суспільства. У свою чергу, індивідуалізація навчання викликає необхідність адаптації навчального процесу до слухача [11].

Впровадження сучасних інформаційних технологій у навчальний процес дозволяє підвищити його якість й підсилити освітню складову від застосування інноваційних педагогічних програм і методик, оскільки дає науково-педагогічним працівникам додаткові можливості для побудови індивідуальних освітніх програм слухачам [10].

В умовах сьогодення подальший розвиток системи охорони здоров’я пов’язаний із переходом її до нових умов функціонування для підвищення продуктивності та якості отримуваного продукту, а це потребує цілісних, системних змін, у тому числі і в частині підготовки професійних, компетентних організаторів у системі охорони здоров’я.

Ефективність розвитку особистості керівника закладу охорони здоров’я (далі - керівник 303) го- ловним чином залежить від сформованості у нього професійних компетентностей, що є результатом синтезу його фахового й особистісного начала та виявляється у високому рівні фахової компетенції, розвинених управлінських здібностях, інтелектуальних та особистісних якостях, які гарантують його ефективну самореалізацію.

У процесі підготовки керівника 303 на основі реалізації адаптивного навчання професійно доцільною $є$ фахово-педагогічна взаємодія між фахівцем та науково-педагогічним працівником, що дозволяє забезпечити керівника 303 багатогранними професійними знаннями, комплексно-кваліфікаційними вміннями, здатностями їх застосовувати в різних робочих ситуаціях. Підвищити рівень кваліфікації та якість підготовки керівника 303, забезпечити його готовність до результативної управлінської діяльності можливо за умов гнучкого поєднання особистісної й фахової складових у системі навчання, що передбачає перехід від традиційно-предметного навчання й оцінювання до адаптивно-індивідуального.

Відповідно до цього організація навчального процесу за умов реалізації адаптивної функції має сприяти вирішенню комплексу взаємопов’язаних завдань професійної підготовки керівника 303, зокрема:

- урахування різноманітних психофізіологічних особливостей (уяви та фантазії, мислення і пам’яті тощо) у процесі здійснення адаптивного навчання, здатного за певних умов розвивати ці особливості, готувати до переборення більш складних індивідних негараздів;

- формування й утримання мотивації до навчальної й професійно-адаптивної діяльності керівника 303 в умовах теоретико-практичної професійної підготовки;

- формування індивідуального стилю здійснення професійно-управлінської діяльності, адаптованої до особистісних якостей кожного керівника 303;

- озброєння керівника 303 системою адаптивнорозвивальних способів організації та здійснення організаційної взаємодії з колегами, медичним колективом, пацієнтами щодо реалізації адаптивного підходу до кожного;

- формування потреби й здатності самоадаптації в процесі роботи;

- оволодіння керівником 303 технологією самовивчення своїх особистісних і професійних особливостей реалізації самоадаптивної функції навчання, взаємодії з іншими людьми, умінь докорінно змінювати лінії власної поведінки [5]. 
Адаптивне навчання актуалізується й особливо ефективно починає функціонувати в умовах безперервних змін, які характерні для сучасного стану вітчизняної системи охорони здоров’я. Ці зміни завжди пов'язані з інноваційними процесами, що мають бути засобом стимулювання активності й самостійності керівників 303 та механізмом підвищення ефективності функціонування системи вищої освіти. Проте, як засвідчує практика, інноваційні процеси потребують ефективного управління ними, створення умов для активної взаємодії суб'єктів й об'єктів навчання, спрямованої на досягнення спільно визначеної мети.

Функціями адаптивного навчання керівних кадрів у сфері охорони здоров'я $є$ : полегшення й стимулювання діяльності керівників 303 у процесі фахової підготовки, максимально наближеної до професійної; створення інтелектуальної та емоційної атмосфери у процесі навчання через досвід; надання педагогічної допомоги та психологічної підтримки у вирішенні проблемних, професійно значимих ситуацій інтерактивними, фахово доцільними методами безпосередньої взаємодії учасників освітнього процесу. В цьому контексті провідна роль належить навчально-виховному професійно спрямованому процесу [5].

Ефективність адаптивного навчання і його результативність залежать від багатьох чинників. Зокрема, від взаємодії та взаємоадаптації суб’єктів навчально-професійної діяльності з урахуванням можливостей оптимального поєднання спрямовуючих впливів науково-педагогічного працівника й свідомого їх сприйняття керівниками 3О3, що стимулює їхній професійно-педагогічний розвиток без примусу й адміністрування.

Суб’єктність позиції керівника 303 визначається його вмінням ставити перед собою навчальну мету, адекватну власним можливостям, і проектувати свою траєкторію її досягнення відповідно до можливостей. Завдяки цьому актуалізуються процеси самоуправління, зокрема, здатність до самоорганізації, самодисциплінованості, оскільки за таких умов слухач відчуває себе суб'єктом навчальної взаємодії, який не лише адаптується до зовнішніх умов діяльності, а й проектує індивідуальну траєкторію власного професійного розвитку.

Висновки. Отже, здійснення адаптивного навчання керівників закладів охорони здоров'я на основі суб'єкт-суб'єктної взаємодії з науково-педагогічним працівником, спрямоване на вирішення значущих навчальних задач із застосуванням професійно-орієнтованого індивідуального підходу до навчання, сприятиме розвитку особистісних якостей, необхідних для продуктивної роботи стосовно запровадження реформ, вирішення назрілих галузевих проблем, прогнозування очікуваних результатів, а також взаємодії з медичним колективом та пацієнтами, що є засобом формування компетентнісного підходу в процесі їх професійного становлення.

\section{Список літератури}

1. Наказ МОЗ України та АМН України від 12.09.2008 p. № 522/51 "Про затвердження Концепції розвитку вищої медичної освіти в Україні”. - Режим доступу : https:// www.moz.gov.ua/ua/portal/dn_20080912_522_.html.

2. Указ Президента України від 25.06.2013 р. № 344/2013 “Про Національну стратегію розвитку освіти в Україні на період до 2021 року”. - Режим доступу : http://zakon3.rada.gov.ua/laws/show/344/2013.

3. Закон України від 01.07.2014 р. № 1556-VII “Про вищу освіту”. - Режим доступу : http://zakon0.rada.gov. ua/laws/show/1556-18.

4. Федорук П. И. Использование системы EduPRO для организации процесса адаптивного обучения / П. И. Федорук, С. Н. Масловский // Управление системами и машинами. - 2009. - № 4. - С. 84-93.

5. Бондар В. Адаптивне навчання студентів як передумова реалізації компетентнісного підходу до професійної підготовки вчителя / В. Бондар, І. Шапошнікова // Рідна школа. - 2013. - № 11. - С. 36-41.

6. Адаптивне управління: сутність, характеристика, моніторингові системи : колективна монографія / [Г. В. Єльникова, Т. А. Борова, Г. А. Полякова та ін.]. Чернівці : Технодрук, 2009. - 570 с.

7. Опалюк Т. Л. Адаптивне навчання студентів та його структура / Т. Л. Опалюк // Наукові записки. Серія “Педагогіка”. - 2014. - № 2. - С. 57-62.

8. Семиченко В. А. Психологічна структура педагогічної діяльності : навч. посіб. / В. А. Семиченко, В. С. Заслуженюк. - К. : Видав.-поліграф. центр “Київський університет”, 2001. - Ч. І. - 217 с.

9. Федорук П. І. Структура подання навчального матеріалу в адаптивних системах дистанційного навчання та контролю знань / П. І. Федорук // Актуальні питання фармацевтичної та медичної науки та практики : зб. наук. статей. - Запоріжжя, 2008. - Вип. XXII. - С. 53-60.

10. Філоненко М. М. Дослідження взаємозв’язку ефективності професійної підготовки майбутнього лікаря та сформованості його особистісних структур / 
М. М. Філоненко // Технології розвитку інтелекту: відкритий наукометричний електронний журнал лабораторії сучасних інформаційних технологій навчання Інституту психології імені Г. С. Костюка НАПН України. 2015. - T. 1, № 8.

\section{References}

1. Nakaz MOZ ta AMN Ukrainy № 522/51 vid 12.09.2008 "Pro zatverdzhennia Kontseptsii rozvytky vyshchoi medychnoi osvity v Ukraini” [Order of the Ministry of Healthcare of Ukraine №522/51 of September 12, 2008 “On approval of the Concept of development of higher medical education in Ukraine"]. Retrieved from https://www.moz. gov.ua/ua/portal/dn_20080912_522.html [in Ukrainian].

2. Ukaz Prezydenta Ukrainy № 344/2013 vid 25.06.2013 "Pro Natsionalnu stratehiiu rozvytku osvity v Ukraini na period do 2021 roku" [Decree of the President of Ukraine №344/2013 of June 25, 2013 “On the National Strategy for Development of Education in Ukraine until 2021”]. Retrieved from http://zakon3.rada.gov.ua/laws/ show/344/2013 [in Ukrainian].

3. Zakon Ukrainy № 1556-VII vid 01.07.2014 "Pro vyshchu osvitu” [Higher Education Act of Ukraine №1556VII of July 1, 2014]. Retrieved from http://zakon0.rada.gov. ua/laws/show/1556-18 [in Ukrainian].

4. Fedoruk, P.I., \& Maslovskiy, S.N. (2009). Ispolzovaniye sistemy EduPRO dlya organizatsyi protsessa adaptivnogo obucheniya [Using the EduPRO system to organize adaptive learning]. Upravlaushchiye sistemy i mashyny - Control systems and machines, 4, 84-93 [in Russian].

5. Bondar, V., \& Shaposhnikova, I. (2013). Adaptyvne navchannia studentiv yak peredumova realizatsii kompetentnisnoho pidhodu do profesiinoi pidhotovky vchytelia [Students adaptive learning as a prerequisite for the implementation of competency-based approach to training teachers]. Ridna shkola - Native School, 11, 36-41 [in Ukrainian].

6. Yelnikova, H.V., Borova, T.A., Poliakova, H.A. et al. (2009). Adaptyvne upravlinnia: sutnist, kharakterystyka, monitorynhovi systemy [Adaptive management: the
11. Філоненко М. М. Системний аналіз процесу особистісного становлення майбутнього лікаря / М. М. Філоненко // Освіта та розвиток обдарованої особистості. Серія “Педагогіка” та “Психологія”. - К., 2015. № 1 (32). - С. 17-21.

essense, characteristics, monitoring systems]. Chernivtsi: Tekhnodruk [in Ukrainian].

7. Opaliuk, T.L. (2014). Adaptyvne navchannia studentiv ta yoho struktura [Students adaptive learning and its structure]. Naukovi zapysky. Pedahohika - Bulletin. Pedagogy, 2, 57-62 [in Ukrainian].

8. Semichenko, V.A., \& Zasluzheniuk, V.S. (2001). Psykholohichna struktura pedahohichnoi diialnosti [Psychological structure of educational activities]. Kyiv: Vydavnycho-polihrafichnyi tsentr "Kyivskyi universytet" [in Ukrainian].

9. Fedoruk, P.I. (2008). Struktura podannia navchalnoho materialu $\mathrm{v}$ adaptyvnykh systemakh dystantsiinoho navchannia ta kontroliu znan [The structure of the presentation of educational material in adaptive system of distance learning and knowledge control]. Aktualni pytannia farmatsevtychnoi ta medychnoi nauky ta praktyky - Current issues of pharmaceutical and medical science and practice, 27, 53-60 [in Ukrainian].

10. Filonenko, M.M. (2015). Doslidzhennia vzaiemozviazku efektyvnosti profesiinoi pidhotovky maibutnioho likaria ta sformovanosti yogo osobystisnykh struktur [Interrelation of future doctor training efficiency and formation of his personality structures study]. Tehnolohii rozvytku intelektu - Technologies of intelligence development, 1, 8 [in Ukrainian].

11. Filonenko, M.M. (2015). Systemnyi analiz protsesu osobystisnoho stanovlennia maibutnioho likaria [Systematic analysis of the future doctor 's personal formation]. Osvita ta rozvytok obdarovanoi osobystosti. Pedahohika ta Psykholohiia. - Education and development of gifted person. Pedagogy and Psychology, 1 (32), 17-21 [in Ukrainian]. 